\title{
ICT Training Areas for the Extension Personnel: A Study of Uttarakhand State
}

\author{
Deepti Kothari and V. L. V. Kameswari*
}

Department of Agricultural Communication, G.B. Pant University of Agriculture and Technology, Pantnagar, Distt-US Nagar, Uttarakhand, India

*Corresponding author

\section{Keywords \\ Training Needs, Extension System, Information and Communication Technologies, Extension Personnel, Training Module}

\section{Article Info}

Accepted:

18 December 2020 Available Online: 10 January 2021

\section{A B S T R A C T}

Information and Communication Technologies are emerging as a key driver of socioeconomic growth of an economy. Applications of ICTs in agriculture sector are numerous, because of focus on making more informed decisions in agricultural operations right from the production to the marketing of the output. The skills and knowledge of human resource involved in facilitating the process information exchange in agriculture system is to be enhanced for expecting much greater outcomes in light of use of ICTs for agricultural development. Considering this, inference it is needed that structured training interventions are planned for developing required and essential ICT competencies amongst the extension professionals. The research study has been conducted on extension functionaries of Uttarakhand State with the objective of outlining the ICT training needs. A total of 291 extension professionals and 30 extension supervisors employed in the public extension system comprising of state departments, KVKs and ICAR institutions were selected randomly for the purpose of the study. The results of the study stated that majority of the extension workers were male $(67.35 \%)$, had less than 10 years of work experience $(62.89 \%)$, specialized in agricultural sciences $(47.77 \%)$, possess majority of the mass media means and presence in social media platforms and kept neutral attitude towards use of ICTs $(71.82 \%)$. Similarly, most of the extension supervisors were also male (76.76\%), had working experience of 11 to 21 years $(43.33 \%)$, specialized in agricultural sciences $(43.33 \%)$, owned most of the mass media means, were present in many of the social media platforms and kept neutral attitude towards use of ICTs $(80 \%)$. Both the supervisors and extension personnel identified application of mobile phones in agricultural extension and social media in agricultural extension as their ICT training needs. In terms of application of mobile phone, the need of training in development of mobile application and mobile application for facilitating extension was ranked as a top priority. The training needs related to use of social media were mostly related to understanding the use of social networking platforms and social networking based softwares in performing extension services were highlighted by both supervisors and extension workers. The study concluded that the ICT training needs for the extension personnel of the Uttarakhand must be strategically placed into the agenda of training agencies by development training modules and must be worked upon for putting up a demand-driven, market oriented and need-based agricultural extension system into place. 


\section{Introduction}

In any society, the basic inputs for rural development and socio-economic progress are knowledge and information (Balit, 1999). Therefore, the role of information technologies especially those, which facilitate the process of communication is very crucial for bringing the socio-economic revolution. These technologies comprises of a wide range of devices, networks, services, applications, software, methods and technologies which are pivotal for storing, managing, processing, retrieving and communicating the information and are commonly identified with an umbrella term "Information and Communication Technologies". ICTs ranges from very conventional and simple audio visual aids such as transparencies, slides, tapes, cassette recorders, radio, newspaper, etc. to complex and modern tools like computers, smart phones, internet, satellites, sensors, GPS, AI interface based softwares and devices and many others. The older ICTs are known as analogue media whereas the new ICTs are termed as Digital Media. These tools work combine to form a networked world of massive infrastructure of interconnected services, systems and networks to make the information accessible to people across the globe.

ICTs have transformed the human ecosystem by accelerating access of people to services, information and other technologies (Nandi, 2002; Dutton et al., 2004). The flexibility and adaptability of ICTs have facilitated the sharing of information and knowledge (Bie, 1996) meeting the diverse requirement and skills of people (Okyere and Mekonnen, 2012).ICTs have found its application in business, social, and public functions leading to transformation of developing societies into digital economies as a consequence of the phenomenon of informatization ( $\mathrm{Li}, 2009$; Obidike, 2011). ICT experiments which were taken up across the world have evidently proved that offer basket of benefits in terms of increasing income, enhancing opportunities of health care, education, employability, training, enterprise development, agricultural productivity, and easy as well as transparent management of systems. ICT investment offers multiple benefits to a nation by impacting the economic performance, decreasing the administrative burden of firms by introduction of e-government applications, enabling access to relevant information, facilitating training and advisory services and reducing the transaction cost as well as saving time. Similarly, advent of ICTs in agriculture led to discovering new prospects of ICTs, thereby making it more demand, market and need-oriented. The promising approach of ICT4Ag to redefine research-extensionfarmer relationship to facilitate information services for the farmers (Gakuru et al., 2009)has led to initiation of many experiments and multiple innovations at grassroots.

Indian agriculture is characterized by weak linkages in the Research-Extension-FarmerInput-Linkage System (REFILS), which leads to a low degree of market integration and connectivity and lack of accessibility to reliable and timely information to the farmers on prices of commodities, also need to work upon an ICT4Ag infrastructure. As advocated by Steinmueller (2001) that major challenges of 'leapfrog' traditional methods of increasing productivity and ensuring sustained food security can be achieved by deploying ICT by the developing and emerging countries. A policy document by Rao (2008) also explicitly stated that, with the current annual population growth of 15.5 million and existing policies, it would be difficult for India to keep pace with the rural development, until the government redefines its policies and strategies, deploy innovations of information and communication 
technologies (ICTs) with active participation from development organizations (DOs).Apart from this, absorptive capacities, appropriate level of human capital and share of $R \& D$ expenditures are essential for a nation to harness the potential of ICTs in any prospective field of development (Keller, 1996). Therefore, in order to bring radical changes in agriculture system of India not only ICTs are vital and but development of required ICT competencies amongst the extension professionals is also equally important.

Thus, in order to make ICT-based extension more effective, both the general public and extension personnel have to be competent in using technology (Hamernik and Crosby, 2015). According to, Vijayraghavan and Singh (2005) development of requisite competencies amongst the extension workforce within extension organizations is directly linked to training of extension personnel. Regular and continuous quality training courses aids in improvement of perception and awareness of extension personnel in using extension methods and aids for dissemination of agricultural technologies (Al-Mashhadaniet al., 2017). And especially in Uttarakhand where presence of weak extension linkage is attributed to the presence of untrained, unskilled, inexperienced workforce (Pandey et al., 2016), ICT training are needed to be worked upon on priority basis. Keeping this in mind the present study was planned to identify the ICT training needs of the grass root extension personnel.

The objectives of the present research study include to study the personal, communication and psychological characteristics of the extension personnel and extension supervisors. Outlining the important ICT training areas for the extension personnel.

\section{Materials and Methods}

Research Design- The design for the present study was analytical type.

Universe of the Study - The present study has been conducted on the Public Extension System of the Uttarakhand State, which is the universe of the present study. PES of Uttarakhand state comprise of three units: ICAR institutions, KVKs (owned by SAUs and ICAR institutions) and State Department (Agriculture, Horticulture, Animal Husbandry and Fisheries)

Research Participants- The respondents for the present research study were 30 extension supervisory staff and 291 field extension personnel from Uttarakhand state of the country.

Research instrument- Pre-tested questionnaire was used as the tool for collection of data for the present research problem from the extension personnel. Interview method was deployed by the researcher for collection of responses from the extension supervisors.

\section{Results and Discussion}

\section{Personal Characteristics of Respondents}

The results of the present study have been mentioned into two sections:

Section I: Characteristics of the extensional personnel and extension supervisors

Section II: Content areas of ICT training modules (Main modules as well as submodule areas) for the extension personnel.

\section{Characteristics of the extensional personnel and extension supervisors}

The empirical data pertaining to the personal, 
communication and psychological characteristics of both the categories of respondents i.e., the extension supervisors as well as extension personnel have been given in the Table 1, 2 and 3 below.

\section{Personal characteristics of respondents}

Sex: It has been clearly documented in the Fig.1 that maximum number of extension supervisors were males i.e., 76.76 per cent followed by 23.33 per cent females. Similarly, more than half i.e., 67.35 per cent of the extension personnel were also male and remaining 32.65 per cent were females.

Years of working experience: In terms of the years of working experience, as stated in Fig. 2 most of the extension supervisors i.e., 43.33 per cent were having an experience of 11 to 21 years closely followed by 36.67 per cent supervisors having more than 21 years of experience and remaining 20 per cent had an experience of less than 10 years. In case of extension personnel, 62.89 per cent had working experience of upto 10 years, followed by 35.39 per cent having experience of 11 to 21 years and 1.72 per cent having more than 21 years of experience (Fig. 2).

\section{Area of specialization}

Fig. 3 gives an illustration of thearea of specialization of both the respondents, it displays that most of the surveyed extension supervisors i.e., 43.33 per cent were from agricultural sciences, followed by 26.67 per cent from horticultural sciences, 16.67 per cent from fisheries sciences and 13.33 per cent from veterinary and animal sciences. Similarly for extension personnel also majority i.e., 47.77 per cent were specialized in agricultural sciences, followed by 20.62 per cent in horticultural sciences, 19.93 per cent in veterinary and animal sciences, 9.96 per cent in fisheries sciences and remaining 1.72 per cent were having social sciences as their area of specialization (Fig. 3).

\section{Communication Characteristics of the Respondents}

Media ownership: Table 1 revealed the media ownership data of the extension supervisors. It stated that cent per cent respondents subscribed to newspaper and owned a smartphone, followed by television (93.33\%), landline telephone (73.33\%), subscription of magazines/journals (66.67\%), computer with internet $(43.33 \%)$, radio (36.67\%), simple mobile phone (30\%), laptop $(23.33 \%)$, and computer without internet $(20 \%)$. None of the surveyed supervisors owned a Tablet. Also for the extension personnel it can be seen that the top five mass-media owned by the extensionists were television (95.19\%), newspaper (91.06\%), smart phone $(81.44 \%)$, computer with internet $(72.16 \%)$ and magazines/journals (62.20\%), whereas landline phone (45.36\%), simple mobile phone $(42.95 \%)$, radio $(26.46 \%)$, tablet (22.68\%), laptop (21.99\%) and computer without internet $(9.97 \%)$ was owned by less than half of the respondents (Fig.6). Similar results have also been documented in the study by Yakubu et al., (2014), Gangadharan (2015), Muqwisi et al., (2015) and Mathuabirami et al., (2019).

\section{Social media usage}

Perusal of Table 1 also revealed that in terms of utilizing social media, cent per cent extension supervisors used e-mail and WhatsApp, followed by Facebook (96.67\%), You Tube channel $(73.33 \%)$, Linked In and Twitter $(56.67 \%$ each), institutional website (53.33\%), agricultural websites/ portals (46.67\%), Instagram (40\%), mobile-based agricultural apps $(33.33 \%)$ and expert system (20\%).The data presented in Table 1 shows that usage of all social media was high among extension personnel. It was found that 
maximum number of respondents $(90.72 \%)$ used e-mail, followed by institutional websites (86.94\%), WhatsApp (86.94\%), Facebook (79.73\%), Twitter (78.69\%), agricultural websites/ portals $(75.26 \%)$, Linked In (74.23\%), You Tube channel (68.04\%), Instagram (68.04\%), mobile-based agricultural apps $(63.57 \%)$ and expert system $(62.20 \%)$.

\section{Psychological Characteristics of the Respondents}

Attitude towards use of ICTs: Fig. 4 revealed that majority of the extension supervisors $(80 \%)$ had neutral attitude towards use of ICTs, and remaining 20 per cent had favourable attitude towards use of ICTs. None of the supervisors had unfavourable attitude towards use of ICTs. Similarly in case of extension personnel, as depicted in Fig. 4, majority (71.82\%) had neutral attitude towards use of ICTs, followed by favourable attitude towards ICTs (23.37\%) and remaining 4.81 per cent had unfavourable attitude. The findings find congruence with the results stated in various research studies conducted so far (Verma et al., 2012; Raksha et al., 2014; Baig, 2015; Gangadharan, 2015).

\section{Content areas of the ICT training module for the extension personnel}

This section stated the results about the opinion of the extension supervisors and extension personnel on the content area of ICT training module. Each of the major areas of ICT training and their sub-areas has been identified after referring to the literature available. The responses of the responses were gathered for 7 major modules with different number of sub-modules in each of the main content areas.

\section{Training needs in seven major areas of ICT training}

ICT training content areas were assessed in 7 major areas viz., Introduction to ICTs in Agricultural Extension, Role of computers in Agricultural Extension, Common software packages, Application of Mobile Phones in Agricultural Extension, Internet/ WWW/ emails /search engines in Agricultural Extension, Social media in Agricultural Extension and Digital content management by both the supervisors as well as the extension personnel and has been documented in Table 2. On the basis of weighted means score, the content area of application of mobile phone in extension as well as social media in agricultural extension were rated I with WMS of 3 and 2.87 and 3 and 2.87 by supervisors and extensionists respectively. The area of digital content management was given II rank by supervisors (WMS=2.90) and also by extensionists (WMS=2.81). The content area of Internet/WWW/ e-mails/ search engines in agricultural extension was given II rank by supervisors (WMS 2.90) and III by extension personnel (WMS=2.77). Common software packages were given IV rank by both the supervisors and the extension personnel (WMS=2.30 and 2.62). The role of computers in agricultural extension was given $\mathrm{V}$ rank with WMS of 1.90 and 2.13 by both the supervisors and the extension personnel. The content area related to the aspect of introduction of ICTs in agricultural extension was given III rank by the supervisors $(\mathrm{WMS}=2)$ and VI rank by the extension personnel (WMS=1.22). Therefore, it can be concluded that the top III rank was occupied by ICT content areas viz., application of mobile phones in agricultural extension, internet/ WWW/ e-mails /search engines in agricultural extension, social media in agricultural extension and digital content management. On the other side, IV, V and VI rank were given to the ICT content areas on introduction to ICTs in agricultural extension, role of computers in agricultural extension and common software packages. 
Training needs in sub-areas of each major areas of ICT training

\section{Introduction to ICTs in Agricultural Extension}

A scrutiny of Table 3 stated that amongst various sub-modules related with the main module on introduction to ICTs in agricultural extension, the content area of recent advances in extension approaches was given I rank by both the supervisors (WMS=3) as well as the extension personnel (WMS=2.23). Submodule on cyber extension/ e-extension was given II rank with WMS 2.90 and 2.15 by both the supervisors and the extension personnel. The sub-module on advantages and disadvantages of using ICTs for extension activities was given II rank by the supervisors (WMS=2.80) and IV rank by the extension personnel (WMS=2.06). Problems in use of ICTs was give IV rank by the supervisors $(\mathrm{WMS}=2.17)$ and III rank by the extension personnel (WMS=2.07).

Table.1 Distribution of the respondents on the basis of communication characteristics

\begin{tabular}{|c|l|c|c|}
\hline Sl. No. & Category & Extension Supervisors & Extension Personnel \\
\hline A. & Media Ownership* & $30(100)$ & $265(91.06)$ \\
\hline $\mathbf{1 .}$ & Newspaper & $30(100)$ & $237(81.44)$ \\
\hline $\mathbf{2 .}$ & Smart phone & $28(93.33)$ & $277(95.19)$ \\
\hline $\mathbf{3 .}$ & Television & $22(73.33)$ & $132(45.36)$ \\
\hline $\mathbf{4 .}$ & Landline telephone & $20(66.67)$ & $181(62.20)$ \\
\hline $\mathbf{5 .}$ & Magazines/ Journals & $13(43.33)$ & $210(72.16)$ \\
\hline $\mathbf{6 .}$ & Computer with internet & $11(36.67)$ & $77(26.46)$ \\
\hline $\mathbf{7 .}$ & Radio & $9(30)$ & $125(42.95)$ \\
\hline $\mathbf{8 .}$ & Mobile phone (simple) & $7(23.33)$ & $64(21.99)$ \\
\hline $\mathbf{9 .}$ & Laptop & $6(20)$ & $29(9.97)$ \\
\hline $\mathbf{1 0 .}$ & Computer without internet & $0(0.00)$ & $66(22.68)$ \\
\hline $\mathbf{1 1 .}$ & Tablet & $30(100)$ & $264(90.72)$ \\
\hline B. & Social Media Usage* & $30(100)$ & $237(81.44)$ \\
\hline $\mathbf{1 .}$ & E-mail & $29(96.67)$ & $232(79.73)$ \\
\hline $\mathbf{2 .}$ & Whats App & $22(73.33)$ & $198(68.04)$ \\
\hline $\mathbf{3 .}$ & Facebook & $17(56.67)$ & $229(78.69)$ \\
\hline $\mathbf{4 .}$ & YouTube Channel & $17(56.67)$ & $216(74.23)$ \\
\hline $\mathbf{5 .}$ & Twitter & $16(53.33)$ & $253(86.94)$ \\
\hline $\mathbf{6 .}$ & Linked In & $14(46.67)$ & $219(75.26)$ \\
\hline $\mathbf{7 .}$ & Institutional websites & $12(40.00)$ & $197(67.70)$ \\
\hline $\mathbf{8 .}$ & Agricultural websites/ portals & $10(33.33)$ & $185(63.57)$ \\
\hline $\mathbf{9 .}$ & Instagram & & \\
\hline $\mathbf{1 0}$. & Mobile-based agricultural & $6(20.00)$ & $181(62.20)$ \\
\hline & Apps & & \\
\hline $\mathbf{1 1 .}$ & Expert systems & & \\
\hline & & & \\
\hline
\end{tabular}


Table.2 Training needs in major areas of ICT training

\begin{tabular}{|c|c|c|c|}
\hline $\begin{array}{l}\text { Sl. } \\
\text { No. }\end{array}$ & Major ICT training need areas & $\begin{array}{c}\text { Extension Supervisors } \\
\text { WMS (Rank) }\end{array}$ & $\begin{array}{c}\text { Extension Personnel } \\
\text { WMS (Rank) }\end{array}$ \\
\hline 1. & Introduction to ICTs in Agricultural Extension & 2 (III) & $1.22(\mathrm{VI})$ \\
\hline 2. & Role of computers in Agricultural Extension & $1.90(\mathrm{~V})$ & $2.13(\mathrm{~V})$ \\
\hline 3. & Common software packages & $2.30(I V)$ & $2.62(I V)$ \\
\hline 4. & Application of Mobile Phones in Agricultural Extension & 3 (I) & $2.87(I)$ \\
\hline 5. & $\begin{array}{l}\text { Internet/ WWW/ e-mails /search engines in Agricultural } \\
\text { Extension }\end{array}$ & 2.90 (II) & 2.77 (III) \\
\hline 6. & Social media in Agricultural Extension & $3(\mathbf{I})$ & 2.87 (I) \\
\hline 7. & Digital content management & 2.90 (II) & 2.81 (II) \\
\hline
\end{tabular}

Table.3 Sub-modules areas on Introduction to ICTs in Agricultural Extension

\begin{tabular}{|c|c|c|c|}
\hline \multirow[t]{2}{*}{ Sl. No. } & \multirow[t]{2}{*}{ Sub-modules } & Extension Supervisors & Extension Personnel \\
\hline & & WMS (Rank) & WMS (Rank) \\
\hline 1. & Agricultural Extension System in India & $\begin{array}{l}1.43 \\
\text { (VI) }\end{array}$ & $\begin{array}{l}1.88 \\
(V)\end{array}$ \\
\hline 2. & $\begin{array}{l}\text { Conventional media and methods of } \\
\text { Agricultural Extension }\end{array}$ & $\begin{array}{l}1.50 \\
(V)\end{array}$ & $\begin{array}{l}1.64 \\
(V I)\end{array}$ \\
\hline 3. & Recent advances in extension approaches & $\begin{array}{c}3 \\
\text { (I) }\end{array}$ & $\begin{array}{c}2.23 \\
(I)\end{array}$ \\
\hline 4. & Cyber extension/ e-extension & $\begin{array}{l}2.90 \\
\text { (II) }\end{array}$ & $\begin{array}{l}2.15 \\
\text { (II) }\end{array}$ \\
\hline 5. & $\begin{array}{l}\text { Advantages and disadvantages of using ICTs } \\
\text { for extension activities }\end{array}$ & $\begin{array}{l}2.80 \\
\text { (III) }\end{array}$ & $\begin{array}{l}2.06 \\
\text { (IV) }\end{array}$ \\
\hline 6. & Problems in use of ICTs & $\begin{array}{l}2.17 \\
(I V)\end{array}$ & $\begin{array}{l}2.07 \\
\text { (III) }\end{array}$ \\
\hline
\end{tabular}

Table.4 Sub-modules areas on Role of computers in Agricultural Extension

\begin{tabular}{|c|c|c|c|}
\hline Sl. No. & Sub-modules & $\begin{array}{c}\text { Extension Supervisors } \\
\text { WMS (Rank) }\end{array}$ & $\begin{array}{c}\text { Extension Personnel } \\
\text { WMS (Rank) }\end{array}$ \\
\hline 1. & Overview of computer & $\begin{array}{l}1.63 \\
(\mathbf{V})\end{array}$ & $\begin{array}{l}1.79 \\
(\mathbf{V I})\end{array}$ \\
\hline 2. & Hardware, software and peripherals & $\begin{array}{c}1.63 \\
(V)\end{array}$ & $\begin{array}{c}1.58 \\
(\text { VIII) }\end{array}$ \\
\hline 3. & Understanding the Operating systems & $\begin{array}{c}2.60 \\
(I)\end{array}$ & $\begin{array}{c}2.18 \\
(I)\end{array}$ \\
\hline 4. & Attaching peripheral devices to computer & $\begin{array}{l}1.53 \\
(\mathrm{VI})\end{array}$ & $\begin{array}{l}1.74 \\
\text { (VII) }\end{array}$ \\
\hline 5. & Open Source Software: installing and updating & $\begin{array}{l}1.90 \\
(I V)\end{array}$ & $\begin{array}{l}1.95 \\
(I V)\end{array}$ \\
\hline 6. & System for management of files/folders in computer & $\begin{array}{l}1.90 \\
\text { (IV) }\end{array}$ & $\begin{array}{l}1.90 \\
(V)\end{array}$ \\
\hline 7. & $\begin{array}{l}\text { Basic functions: scanning, burning, compressing, } \\
\text { zipping/ unzipping, format conversion, etc. }\end{array}$ & $\begin{array}{c}2 \\
(I I I)\end{array}$ & $\begin{array}{l}1.96 \\
\text { (III) }\end{array}$ \\
\hline 8. & Computer threats and malware & $\begin{array}{c}2.03 \\
\text { (II) }\end{array}$ & $\begin{array}{c}1.98 \\
\text { (II) }\end{array}$ \\
\hline 9. & Key terminologies related to computer & $\begin{array}{l}1.90 \\
(I V)\end{array}$ & $\begin{array}{l}1.96 \\
\text { (III) }\end{array}$ \\
\hline
\end{tabular}


Table.5 Sub-modules of Common software packages

\begin{tabular}{|c|c|c|c|}
\hline \multirow[t]{2}{*}{ Sl. No. } & \multirow[t]{2}{*}{ Sub-modules } & Extension Supervisors & Extension Personnel \\
\hline & & WMS (Rank) & WMS (Rank) \\
\hline 1. & $\begin{array}{l}\text { MS Word: basic and advanced } \\
\text { features of document preparation }\end{array}$ & $\begin{array}{l}2.13 \\
(\mathrm{VI})\end{array}$ & $\begin{array}{l}1.70 \\
(V I)\end{array}$ \\
\hline 2. & $\begin{array}{l}\text { MS Excel: } \begin{array}{r}\text { Statistical } \\
\text { computations } \\
\text { presentation }\end{array} \text { and } \\
\end{array}$ & $\begin{array}{c}2 \\
(\mathrm{VIII})\end{array}$ & $\begin{array}{l}1.58 \\
(\mathrm{VII})\end{array}$ \\
\hline 3. & $\begin{array}{l}\text { Other statistical software: R, } \\
\text { SPSS, SAS etc. }\end{array}$ & $\begin{array}{l}2.13 \\
(\mathrm{VI})\end{array}$ & $\begin{array}{c}1.72 \\
(\mathrm{~V})\end{array}$ \\
\hline 4. & $\begin{array}{l}\text { MS PowerPoint: } \\
\text { preparing } \\
\text { presentation }\end{array}$ & $\begin{array}{l}2.20 \\
(\mathrm{~V})\end{array}$ & $\begin{array}{l}1.44 \\
(\mathrm{IX})\end{array}$ \\
\hline 5. & $\begin{array}{l}\text { Introduction to Prezi for } \\
\text { specialized presentations }\end{array}$ & $\begin{array}{l}2.53 \\
\text { (III) }\end{array}$ & $\begin{array}{l}1.77 \\
\text { (III) }\end{array}$ \\
\hline 6. & $\begin{array}{l}\text { MS Publisher: Preparing } \\
\text { publications in various formats }\end{array}$ & $\begin{array}{l}2.53 \\
\text { (III) }\end{array}$ & $\begin{array}{c}1.46 \\
(V I I I)\end{array}$ \\
\hline 7. & $\begin{array}{l}\text { Desktop Publishing Software: } \\
\text { Pagemaker, Publisher, etc. }\end{array}$ & $\begin{array}{l}2.57 \\
\text { (II) }\end{array}$ & $\begin{array}{l}1.79 \\
\text { (II) }\end{array}$ \\
\hline 8. & $\begin{array}{l}\text { MS Access: management of } \\
\text { database }\end{array}$ & $\begin{array}{l}2.07 \\
(\text { VII) }\end{array}$ & $\begin{array}{c}1.58 \\
(\mathrm{VII})\end{array}$ \\
\hline 9. & $\begin{array}{l}\text { Working with MS Outlook: } \\
\text { offline mail viewing platform }\end{array}$ & $\begin{array}{l}2.30 \\
\text { (IV) }\end{array}$ & $\begin{array}{l}1.75 \\
(\mathrm{IV})\end{array}$ \\
\hline 10. & $\begin{array}{l}\text { Graphic and drawing software: } \\
\text { Corel Draw, Paint Pro, Illustrator, } \\
\text { etc. }\end{array}$ & $\begin{array}{c}2.63 \\
(I)\end{array}$ & $\begin{array}{c}1.83 \\
(I)\end{array}$ \\
\hline
\end{tabular}

Table.6 Sub-modules of Application of Mobile Phones in Agricultural Extension

\begin{tabular}{|c|c|c|c|}
\hline \multirow[t]{2}{*}{ Sl. No. } & \multirow[t]{2}{*}{ Sub-modules } & Extension Supervisors & Extension Personnel \\
\hline & & WMS (Rank) & WMS (Rank) \\
\hline 1. & $\begin{array}{l}\text { History of development of Mobile } \\
\text { applications for extension } \\
\text { activities }\end{array}$ & $\begin{array}{l}2.30 \\
(I V)\end{array}$ & $\begin{array}{l}2.23 \\
(I V)\end{array}$ \\
\hline 2. & $\begin{array}{l}\text { Mobile phones v/s Computers in } \\
\text { Agricultural Extension }\end{array}$ & $\begin{array}{c}2.80 \\
\text { (II) }\end{array}$ & $\begin{array}{l}2.29 \\
\text { (III) }\end{array}$ \\
\hline 3. & Kisan Call Centers & $\begin{array}{c}1.90 \\
(V)\end{array}$ & $\begin{array}{l}2.19 \\
(I V)\end{array}$ \\
\hline 4. & $\begin{array}{l}\text { Mobile Applications facilitating } \\
\text { interaction-based Extension }\end{array}$ & $\begin{array}{l}2.73 \\
\text { (III) }\end{array}$ & $\begin{array}{r}2.34 \\
\text { (II) }\end{array}$ \\
\hline 5. & $\begin{array}{l}\text { Development of } \quad \text { mobile } \\
\text { applications }\end{array}$ & $\begin{array}{c}2.90 \\
(I)\end{array}$ & $\begin{array}{c}2.62 \\
(I)\end{array}$ \\
\hline 6. & $\begin{array}{l}\text { Advantages and disadvantages of } \\
\text { mobile applications }\end{array}$ & $\begin{array}{l}1.87 \\
(\mathrm{VI})\end{array}$ & $\begin{array}{c}2.10 \\
(\mathrm{~V})\end{array}$ \\
\hline
\end{tabular}


Table.7 Sub-modules of Internet/ WWW/ e-mails/ search engines in Agricultural Extension

\begin{tabular}{|c|c|c|c|}
\hline \multirow[t]{2}{*}{ Sl. No. } & \multirow[t]{2}{*}{ Sub-modules } & Extension Supervisors & Extension Personnel \\
\hline & & WMS (Rank) & WMS (Rank) \\
\hline 1. & Understanding the basics of internet & $\begin{array}{l}1.20 \\
\text { (VII) }\end{array}$ & $\begin{array}{c}2.64 \\
(V)\end{array}$ \\
\hline 2. & Web browsers and search engine & $\begin{array}{l}1.50 \\
(\mathrm{VI})\end{array}$ & $\begin{array}{l}2.26 \\
(I X)\end{array}$ \\
\hline 3. & $\begin{array}{l}\text { Basics of navigation and searching in } \\
\text { the internet }\end{array}$ & $\begin{array}{l}1.80 \\
(V)\end{array}$ & $\begin{array}{c}2.31 \\
(\text { VIII })\end{array}$ \\
\hline 4. & $\begin{array}{l}\text { E-resources for } \text { Agricultural } \\
\text { information }\end{array}$ & $\begin{array}{l}2.27 \\
\text { (III) }\end{array}$ & $\begin{array}{l}2.65 \\
\text { (IV) }\end{array}$ \\
\hline 5. & Overview of Google suite & $\begin{array}{l}2.57 \\
\text { (II) }\end{array}$ & $\begin{array}{l}2.72 \\
\text { (II) }\end{array}$ \\
\hline 6. & E-mail service: Uses and features & $\begin{array}{l}2.57 \\
\text { (II) }\end{array}$ & $\begin{array}{l}2.51 \\
(\text { VII })\end{array}$ \\
\hline 7. & $\begin{array}{l}\text { Creation of online communities and } \\
\text { discussion platforms }\end{array}$ & $\begin{array}{c}2.90 \\
(I)\end{array}$ & $\begin{array}{l}2.67 \\
\text { (III) }\end{array}$ \\
\hline 8. & $\begin{array}{l}\text { Safety issues, copyright and online } \\
\text { ethics (netiquettes) }\end{array}$ & $\begin{array}{c}2.90 \\
(I)\end{array}$ & $\begin{array}{c}2.90 \\
(I)\end{array}$ \\
\hline 9. & Key terminologies related to internet & $\begin{array}{l}2.23 \\
(I V)\end{array}$ & $\begin{array}{l}2.62 \\
(\mathrm{VI})\end{array}$ \\
\hline
\end{tabular}

Table.8 Sub-modules of Social media in Agricultural Extension

\begin{tabular}{|c|c|c|c|}
\hline \multirow[t]{2}{*}{ SI. No. } & \multirow[t]{2}{*}{ Sub-modules } & Extension Supervisors & Extension Personnel \\
\hline & & WMS (Rank) & WMS (Rank) \\
\hline 1. & Introduction to social media & $\begin{array}{c}2.10 \\
(V)\end{array}$ & $\begin{array}{l}2.50 \\
(V I)\end{array}$ \\
\hline 2. & $\begin{array}{l}\text { Use of social networking platforms } \\
\text { for extension }\end{array}$ & $\begin{array}{l}2.77 \\
\text { (II) }\end{array}$ & $\begin{array}{c}2.66 \\
(I)\end{array}$ \\
\hline 3. & $\begin{array}{l}\text { Journalistic writing principles and } \\
\text { techniques for social media }\end{array}$ & $\begin{array}{l}2.33 \\
(I V)\end{array}$ & $\begin{array}{l}2.56 \\
\text { (IV) }\end{array}$ \\
\hline 4. & $\begin{array}{l}\text { Content designing for Radio: Script } \\
\text { writing and presentation basics }\end{array}$ & $\begin{array}{l}2.33 \\
(I V)\end{array}$ & $\begin{array}{l}2.45 \\
(\text { VII })\end{array}$ \\
\hline 5. & $\begin{array}{l}\text { Content designing for Television: } \\
\text { Story board and presentation skills }\end{array}$ & $\begin{array}{l}2.33 \\
(I V)\end{array}$ & $\begin{array}{c}2.54 \\
(V)\end{array}$ \\
\hline 6. & Skills of photography & $\begin{array}{l}2.33 \\
(I V)\end{array}$ & $\begin{array}{c}2.54 \\
(V)\end{array}$ \\
\hline 7. & $\begin{array}{l}\text { Facebook, Twitter, Instagram, } \\
\text { Whatsapp, Hike, Telegram, } \\
\text { Messenger and other applications for } \\
\text { Extension }\end{array}$ & $\begin{array}{c}2.90 \\
\text { (I) }\end{array}$ & $\begin{array}{c}2.58 \\
\text { (II) }\end{array}$ \\
\hline 8. & $\begin{array}{l}\text { Scope of social media platform for } \\
\text { extension }\end{array}$ & $\begin{array}{c}2.90 \\
(I)\end{array}$ & $\begin{array}{l}2.57 \\
\text { (III) }\end{array}$ \\
\hline 9. & $\begin{array}{l}\text { Limitations and problems of social } \\
\text { networking platforms }\end{array}$ & $\begin{array}{l}2.67 \\
\text { (III) }\end{array}$ & $\begin{array}{l}2.40 \\
(\text { VII })\end{array}$ \\
\hline
\end{tabular}


Table.9 Sub-modules of Digital content management

\begin{tabular}{|c|c|c|c|}
\hline \multirow[t]{2}{*}{ Sl. No. } & \multirow[t]{2}{*}{ Sub-modules } & Extension Supervisors & Extension Personnel \\
\hline & & WMS (Rank) & WMS (Rank) \\
\hline 1. & $\begin{array}{l}\text { An introduction to informational } \\
\text { space on WWW }\end{array}$ & $\begin{array}{l}2.70 \\
\text { (IV) }\end{array}$ & $\begin{array}{l}2.43 \\
\text { (VI) }\end{array}$ \\
\hline 2. & $\begin{array}{l}\text { Agricultural knowledge } \\
\text { management and WWW }\end{array}$ & $\begin{array}{c}2.90 \\
(I)\end{array}$ & $\begin{array}{l}2.54 \\
\text { (II) }\end{array}$ \\
\hline 3. & $\begin{array}{l}\text { Basics of web designing software: } \\
\text { HTML, CSS etc. }\end{array}$ & $\begin{array}{c}2.90 \\
(I)\end{array}$ & $\begin{array}{c}2.61 \\
(I)\end{array}$ \\
\hline 4. & Creation of You Tube Channel & $\begin{array}{l}2.73 \\
\text { (III) }\end{array}$ & $\begin{array}{l}2.50 \\
\text { (III) }\end{array}$ \\
\hline 5. & $\begin{array}{l}\text { Introduction to blogs and skills of } \\
\text { blog writing }\end{array}$ & $\begin{array}{l}2.73 \\
\text { (III) }\end{array}$ & $\begin{array}{l}2.37 \\
(\text { VII })\end{array}$ \\
\hline 6. & $\begin{array}{l}\text { Overview of Decision Support } \\
\text { System }\end{array}$ & $\begin{array}{l}2.80 \\
\text { (II) }\end{array}$ & $\begin{array}{l}2.50 \\
\text { (III) }\end{array}$ \\
\hline 7. & Development of an Expert system & $\begin{array}{r}2.80 \\
\text { (II) }\end{array}$ & $\begin{array}{c}2.44 \\
(V)\end{array}$ \\
\hline 8. & $\begin{array}{l}\text { Presentation, updating, promotion } \\
\text { and uploading/downloading of } \\
\text { digital content on WWW }\end{array}$ & $\begin{array}{c}2.80 \\
\text { (II) }\end{array}$ & $\begin{array}{l}2.49 \\
\text { (IV) }\end{array}$ \\
\hline
\end{tabular}
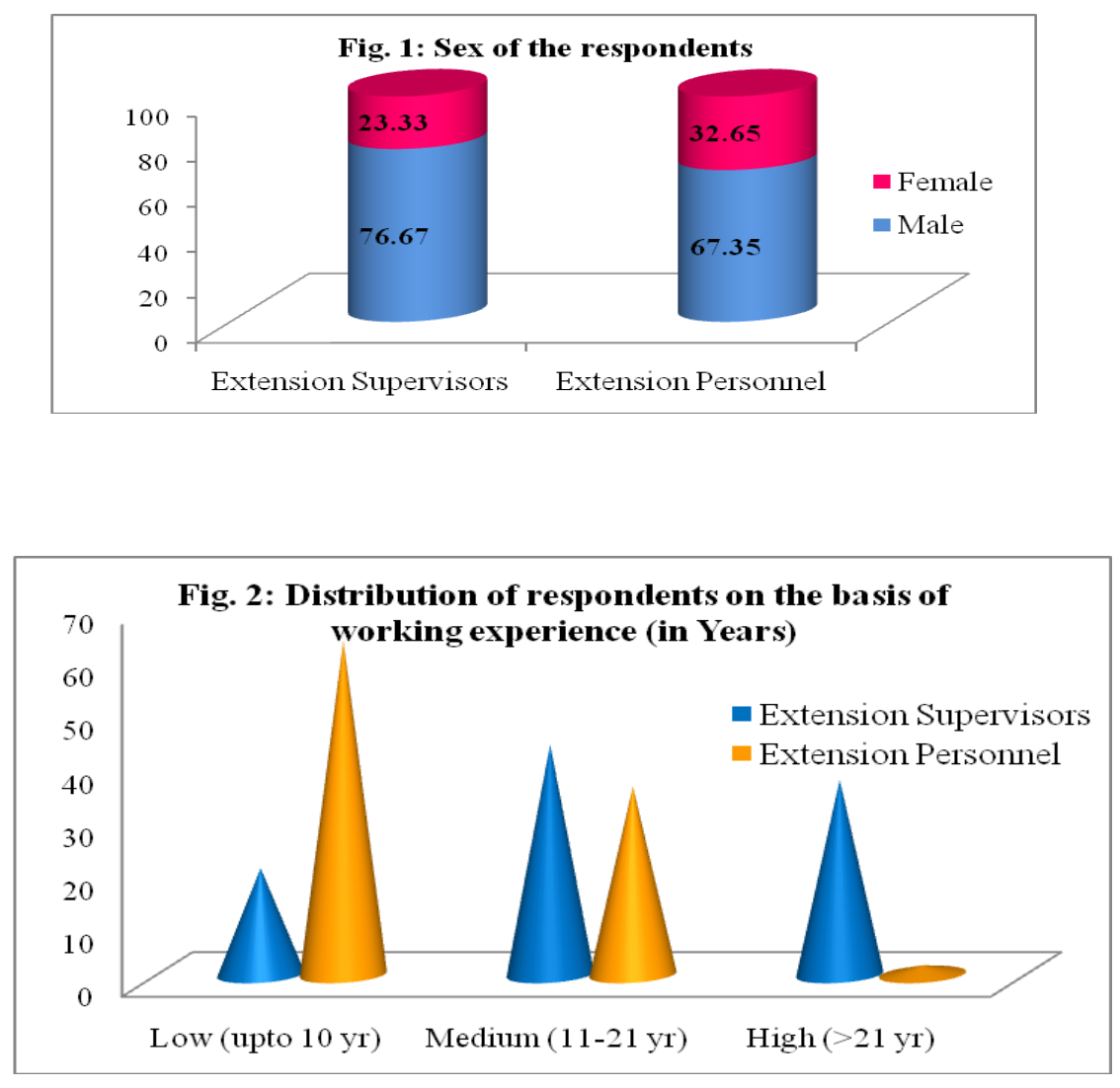

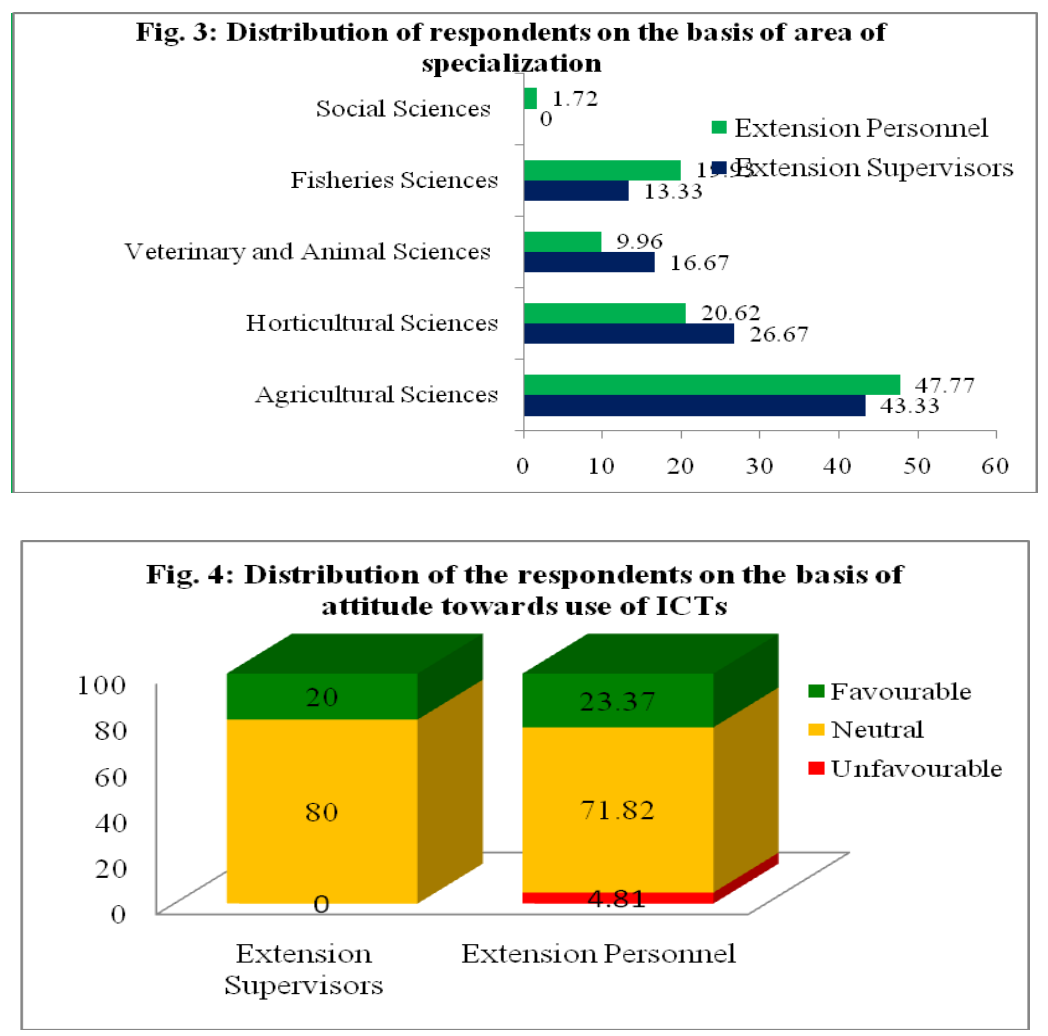

The sub-module content area on agricultural extension system on India was rated VI with WMS of 1.43 by the supervisors and V with WMS of 1.88 by the extension personnel. The sub-module related to conventional media and methods of agricultural extension was given $\mathrm{V}$ and VI rank by the supervisors and the extension personnel with WMS of 1.50 and 1.64 respectively. Thus, it can be concluded that the top III sub-modules of the main module on introduction of ICTs in agricultural extension were recent advances in extension approaches, cyber extension/ eextension, advantages and disadvantages of using ICTs for extension activities and problems in use of ICTs.

\section{Role of computers in Agricultural Extension}

The sub-module content areas on ICT training under the major area of role of computers in agricultural extension can be well comprehended by examining Table 4 . The sub-module on understanding the operating systems was given I rank by both the supervisors and extension personnel with WMS of 2.60 and 2.18 respectively. Submodule content area on computer threats and malware was given II rank by both supervisors and the extension personnel with WMS of 2.03 and 1.98 respectively. The submodule content on basic functions: scanning, burning, compressing, zipping/ unzipping, format conversions etc. was ranked III with WMS of 2 and 1.96 by both the supervisors and the extension personnel. Key terminologies related to computer sub-module was placed at IV rank by the supervisors (WMS=1.90) and III rank by the extension personnel (WMS=1.96). The sub module related to the open system software: installing and updating was positioned at IV rank by supervisors (WMS $=1.90)$ as well as the extension personnel (WMS=1.95). System for management of files/folders in computer submodule was given IV rank by the supervisors (WMS=1.90) and V rank by the extension 
personnel (WMS=1.90). Sub-module on overview of computer was ranked $\mathrm{V}$ by the supervisors (WMS $=1.63$ ) and VI by the extension personnel (1.79). Similarly, the submodule on hardware, software and peripherals was also ranked $\mathrm{V}$ by the supervisors (WMS=1.63) and VIII by the extension personnel (WMS=1.58). In case of submodule related to content on attaching peripheral devices to the computer was placed at the VI rank by the supervisors (WMS=1.53) and VII rank by the extension personnel (WMS=1.74). The content of submodules that were placed at I, II and III rank by both categories of the respondents under the main module on role of computer in agricultural extension were viz., understanding the operating systems, computer threats and malware, basic functions: scanning, burning, compressing, zipping/unzipping, format conversions etc. and key terminologies related to computer.

\section{Common software packages}

An analysis of Table 5 will help to understand the preference for the various sub-module content areas under the main module area on common software packages. The sub-module on graphic ad drawing software: coral draw, paint pro, illustrator etc. was ranked I by both the supervisors (WMS=2.63) and the extension personnel (WMS=1.83). II rank was given to the sub-module on desktop publishing software: pagemaker, publisher etc. by the supervisors (WMS=2.57) as well as the extension personnel (WMS=1.79). The sub-module on introduction to Prezi for specialized presentations was given III rank by supervisors (WMS=2.53) and the extension personnel (WMS=1.77). Submodule content area related to MS publisher: preparing publications in various formats was given III rank by the supervisors with WMS of 2.53, whereas VIII rank by the extension personnel with WMS of 1.46. The sub- module on working with MS outlook: offline mail viewing platform was given IV rank by the supervisors (WMS=2.30) and the extension personnel (WMS=1.75). MS powerpoint: skills of preparing professional presentation sub-module content area was given $\mathrm{V}$ rank by the supervisors $(\mathrm{WMS}=2.20)$ and IX rank by the extension personnel (WMS=1.44). The sub-module related to content on other statistical software: R, SPSS, SAS, etc. was placed at VI rank by the supervisors (WMS=2.20) and $\mathrm{V}$ rank by the extension personnel (WMS=1.72). The content area of sub-module on MS work: basic and advanced features of document preparation was given VI rank by the supervisors (WMS=2.13) and the extensionists (WMS $=1.70)$ as well. MS Access: management of database sub-module was given VII rank by supervisors and the extension personnel with WMS of 2.07 and 1.58 respectively. The sub-module on content area MS excel: statistical computations and data presentation was given VIII rank by the supervisors (WMS=2) and VII rank by the extension personnel. Therefore, it can be concluded that the top III sub-module content areas agreed by both categories of respondents were related to graphic and drawing software: corel draw, paint pro, illustrator, etc., introduction to Prezi for specialized presentations and desktop publishing software: pagemaker, publisher, etc.

\section{Application of Mobile Phones in Agricultural Extension}

Scrutiny of Table 6 revealed the sub-module content area preferences of the supervisors and the extension personnel related to main module on application of mobile phones in agricultural extension. Sub-module content related to development of mobile applications was given I rank by the supervisors as well as the extension personnel with WMS of 2.90 
and 2.62 respectively. II rank was given to content area on mobile phone v/s computers in agricultural extension by the supervisors (WMS=2.80) and III rank by the extension personnel (WMS=2.29). The content area on sub-module entitled mobile applications facilitating interaction-based extension was given III rank by the supervisors (WMS=2.73) and II rank by the extension personnel (WMS=2.34). Sub-module related to content on history of development of mobile applications for extension activities was placed at IV rank by both the supervisors and the extension personnel with WMS of 2.30 and 2.23 respectively. Sub-module content on kisan call centers was given $\mathrm{V}$ rank by the supervisors (WMS $=1.90)$ and IV rank by the extension personnel (WMS=2.19). The sub module on content based on advantages and disadvantages of mobile applications was given VI rank by the supervisors $(\mathrm{WMS}=1.87)$ and $\mathrm{V}$ rank by the extension personnel (WMS=2.10). It can therefore, be concluded that the top three priority content areas for sub module on applications of mobile phones in agricultural extension were viz, development of mobile applications, mobile applications facilitating interaction-based extension and mobile phones v/s computers in agricultural extension.

\section{Internet/ WWW/ e-mails/ search engines in Agricultural Extension}

The preference of content areas related with sub-modules of main module on internet/ WWW/ e-mails/ search engines in agricultural extension has been clearly documented in Table 7. The content related with sub-module on safety issues, copyright and online ethics (netiquettes) was given I rank by the both the supervisors (WMS=2.90) and the extension personnel (WMS=2.90). Creation of online communities and discussion platforms related sub-module content area was placed at I rank by the supervisors (WMS=2.90) and at the III rank by the extension personnel (2.67). Submodule on overview of google suite was given II rank by both the supervisors and the extension personnel with WMS of 2.57 and 2.72 respectively. The sub-module content areas on e-mail services: uses and features have been placed at II rank by the supervisors (2.57) and VII rank by the extension personnel (2.51). E-resources for agricultural information related content in the sub-module was given III rank by the supervisors (WMS=2.27) and IV rank by the extension personnel (WMS=2.65). The sub-module on content area of key terminologies related to internet was given IV rank by the supervisors (WMS=2.23) and VI rank by the extension personnel (WMS=2.62). Basics of navigation and searching in the internet was placed at $\mathrm{V}$ position by the supervisors (WMS $=1.80)$ and VIII position by the extension personnel (WMS=2.31). The sub-module on content area web browsers and search engines was give VI and IX rank by the supervisors and the extension personnel with WMS of 1.50 and 2.26 respectively. The content area of sub-module on understanding the basics of internet was given VII rank by the supervisors $(\mathrm{WMS}=1.20)$ and $\mathrm{V}$ rank by the extension personnel (WMS=2.64). Overall, it can be concluded that the top III preferences for submodule content areas on main module related with internet/ WWW/ e-mails/ search engines in agricultural extension were safety issues, copyright and online ethics (netiquettes), creation of online communities and discussion platforms and the overview of google suite. Okoedo-Okojie and Edobor (2013) also reported the training needs related to internet for the extension professionals.

\section{Social media in Agricultural Extension}

Table 8 clearly highlights the sub-module content areas under the main module entitled as social media in agricultural extension. The 
sub-module related with content on facebook, twitter, Instagram, whatsapp, hike, telegram, messenger and other applications for extension was given I rank by the supervisors (WMS =2.90) and II by the extension personnel (WMS=2.58). The sub module on scope of social media platform for extension was given I and III rank by the supervisors and the extension personnel with WMS of 2.90 and 2.57 respectively. The sub-module on use of social networking platforms for extension was placed at II rank by the supervisors (WMS $=2.77$ ) and I rank by the extension personnel (WMS=2.66). Limitations and problems of social networking platforms sub-module content area was given III rank by the supervisors (WMS=2.67) and VII rank by the extension personnel (WMS=2.40). Content of submodule on journalistic writing principles and techniques for social media was given IV rank by the supervisors (WMS=2.33) as well as by the extension personnel (WMS=2.56). The sub-modules on both content designing for television: story board and presentation skills as well as skills in photography was given IV rank by the supervisors $(\mathrm{WMS}=2.33)$ and $\mathrm{V}$ rank by the extension personnel (WMS=2.54). Content designing for radio: script writing and presentation basics sub-module was also given IV rank by the supervisors (WMS=2.33), whereas VII rank by the extension personnel (WMS=2.45). The submodule content related to introduction to social media was given $\mathrm{V}$ rank by the supervisors (WMS $=2.10$ ) and VI rank by the extension personnel (WMS=2.50). Therefore, it can be summarized that the top III submodule content agreed by both supervisors and the extension personnel for the main module entitled as social media in agricultural extension were facebook, twitter, instagram, whatsapp, hike, telegram, messenger and other applications for extension, scope of social media platform for extension and use of social networking platforms for extension.
The findings of study conducted by Thomas and Lasinde (2015) also focusses on training areas in content of social networking platforms viz, facebook, twitter, you tube and blogs.

\section{Digital content management}

A perusal of Table 9 indicated the preferences for content on sub-modules under the main module on digital content management. Submodule on content related with basics of web designing software: HTML, CSS etc. was given I rank by the supervisors as well as the extension personnel with WMS 2.90 and 2.61 respectively. The content on agricultural knowledge management and WWW was given I rank by the supervisors (WMS $=2.90)$ and II rank by the extension personnel (WMS=2.54). The sub-module on overview of decision support system was given II rank by the supervisors (WMS=2.80) and III rank by the extension personnel (WMS=2.50). Development of expert system sub-module was given II rank by the supervisors (WMS=2.80) and $\mathrm{V}$ rank by the extension personnel (WMS=2.44). The sub-module on content area presentation, updating, promotion and uploading/ downloading of digital content on WWW was given II rank by the supervisors and IV rank by the extension personnel with WMS of 2.80 and 2.4 respectively. Creation of you tube channel sub-module was given III rank by both the supervisors and the extension personnel as well with WMS of 2.73 and 2.50. The submodule on content area introduction to blogs and skills of blog writing was given III rank by the supervisors (WMS=2.73) and VII rank by the extension personnel (WMS=2.37). The sub-module on content related to an introduction to informational space on WWW was given IV rank by the supervisors $(\mathrm{WMS}=2.70)$ and VI ran by the extension personnel (WMS=2.43). Thus, it can be concluded that the top III content areas of 
sub-module under the main module of digital content management agreed by both the supervisors and the extension personnel were basics of web designing software: HTML, CSS etc., agricultural knowledge management and WWW, overview of decision support system and creation of you tube channel.

In conclusion the present study outlines many important areas of ICT Training Needs for the grass root extension personnel of the Uttarakhand State. The findings focus that ICT competency aspects that are to be focussed keeping in mind the developmental needs of a mountainous state like Uttarakhand are mainly in context of use of mobile and social media based extension. Therefore, it is essential that the training interventions, package of practices, training modules, induction and in-services training for the grassroot extension functionaries of the state must be developed, designed and implemented with a proper action plan considering the identified key priority training areas. The findings will help the state to formulate its own state ICT policy for reaping the benefits of ICTs in meeting the targets of socio-economic development of the government. Further, such initiatives will serve as a role model for other states having similar topographical concerns to adapt and implement the mechanism of ICT trainings for developing the required human resource base with the needed competencies in using ICTs for agricultural extension.

\section{Acknowledgements}

The author would like to acknowledge UGC for funding the above mentioned work of Ph.D. degree programme through NET-JRF Fellowship and her guide who is second author of this manuscript for giving her time, inputs and support and also all the faculty members of Department of Agricultural Communication, College of Agriculture, G.B.
Pant University of Agriculture and Technology, Pantnagar for helping in conceptualizing the research problem and giving necessary inputs in conducting the research study.

\section{References}

Al-Mashhadani, A. L. J., Magd, Z. H. and Keshta, A. E. A. (2017).Levels of Use and Importance of Extension Methods and Aids in the Process of Dissemination of Agricultural Technologies in the Republic of Iraq. IOSR Journal of Agriculture and Veterinary Science, 10(5): 1-6. doi: 10.9790/2380-1005020106

Baig, R. (2015). Extent of utilization of ICT tools among field veterinarians of Andhra Pradesh. Unpublished M.Sc. Thesis.Department of Veterinary and Animal Husbandry Extension Education, College of Veterinary Science, Sri Venkateswara Veterinary University, Tirupati - 517 502, India.

Balit, S. (in collaboration with FAO communication for development group) (1999). Voice for change: Rural women and communication. pp37. FAO. Extension and Training Division. Communication for development group, Extension Education and Communication services.

Bie, S. (1996).Development Communication and Internet.FAO.Research, Extension and Training Division, FAO, Rome, Italy.

Dutton, W. H., Gillett, S. E., Mcknight, L. W. and Peltu, M. (2004). Bridging Broadband Internet Divides: Reconfiguring Access to Enhance Communication Power. Journal of Information Technology.19(1): 24-38.

Gakuru, M., Winters, K., Stepman, F. (2009). Innovative farmer advisory services using ICT. In: Paul Cunningham, 
Miriam Cunningham, editors. ISTAfrica 2009 conference proceedings. Uganda: IIMC International Information Management Corporation; 2009, ISBN 978-1-905824-11-3. 06- 08 May 2009.

Gangadharan, C. (2015). Strategies for Capacity Building of Extension Personnel for Using Information and Communication Technologies. Unpublished M.Sc. Thesis, Department of Agricultural Extension, College of Horticulture, Vellanikkara, Thrissur 680656, Kerala, India.

Hamernik.D. and Crosby, G. (2015).Exploring new opportunities for extension.Cooperative Extension Workshop.Available online from http://www.csrees.

usda.gov/about/white_papers/pdfs/explo ring.pdf

Keller, W. (1996). Absorptive Capacity: On the Creation and Acquisition of Technology in Development. Journal of Development Economics 49(1), pp. 199-227.

Li, D. (2009). China rural informatization development 2009 report (in Chinese). Beijing: Publishing House of Electronics Industry.

Mathuabirami, V., Makokha, J. and Karthikeyan, C. (2019). Constraints faced by extension officers of Coimbatore district, Tamil Nadu in using Uzhavan app. International Journal of Farm Sciences, 9(1): 126130. doi: 10.5958/22500499.2019.00030.2

Muqwisi, T., Mostert, J. and Ocholla, D. N. (2015).Access to and Utilization of Information and Communication Technologies by Agricultural Researchers and Extension Workers in Zimbabwe. Journal of Information Technology for Development. 21(1): 6784. Retrieved online from http://www.tandfonline.com/

doi/abs/10.1080/02681102.2013.874317

?journalCode $=$ titd20

Nandi, B. (2002). Role of telecommunications in developing countries in the $21^{\text {st }}$ century, $14^{\text {th }}$ Biannual Conference, International Telecommunication Society, Seoul.

Obidike, N. A. (2011). Rural farmers' problems accessing agricultural information: a case study of Nsukka local government area of Enugu State, Nigeria. Library Philosophy and Practice (ejournal). Paper 660.

Okoedo-Okojie, D. U. and Edobor, E. W. (2013).Identification of Communication Needs of Extension Agents in Ondo State Nigeria. IOSR Journal of Agriculture and Veterinary Science, 4(1): 01-06.

Okyere, A. K. and Mekonnen, D. A. (2012).The Importance of ICTs in the Provision of Information for Improving Agricultural Productivity and Rural Incomes in Africa. Working Paper No. 15.United Nations Development Programme. Regional Bureau for Africa. Available online from https://www.zef.de/ uploads/tx_zefportal/Publications/ece1_ ICT\%20Productivity\%20(1).pdf

Pandey, A. C., Bahuguna, R. and Soodan, V. (2016). Opportunities and Challenges in Managing Rural Development: A Case of Garhwal Region of UttarakhandIndia. Intercontinental Journal of Human Resource Management, 3(7): 915.

Raksha, Rao, I. S. and Shaik, N. M. (2014).Attitude of the agricultural extension personnel towards use of information technologies in field work.Journal of Communication Studies, 32(2): 4-10.

Rao, S. S. (2009). Achieving millennium development goals: Role of ICTs 
innovations in India.Telematics and Informatics. 26. pp. 127-143.

Steinmueller, W. E. (2001). ICTs and possibilities for leapfrogging for developing countries. International Labour Review, 140(2): 193-210.

Thomas, K. A. and Laseinde, A. A. (2015).Training Needs Assessment on the Use of Social Media among Extension Agents in Oyo State, Nigeria. Journal of Agricultural Informatics, 6(1): 100-111. doi:10.17700/jai.2015.6.1.144

Verma, S. R., Sharma, F. L., Chayal, K. and Kaushil, M. K. (2012). Attitude of information and communication technologies in agriculture. Rajasthan Journal of Extension Education, 20:
102-107.

Vijayraghavan, K. and Singh, Y. P. (2005).Managing Human Resources within Extension. In Improving Agricultural Extension: A Reference Manual.Swanson, B. E., Bentz, R. P. and Sofranko, A. J. (Eds).Extension, Education and Communication Service, Research, Extension and Training Division, Sustainable Development Department, FAO.

Yakubu, D. H., Abubakar, B. Z., Atala, T. K. and Muhammed, A. (2014).Use of Information and Communication Technologies among Extension Agents in Kano State. Nigerian Journal of Agricultural Extension, 17(1): 1-12.

\section{How to cite this article:}

Deepti Kothari and Kameswari, VLV. 2021. ICT Training Areas for the Extension Personnel: A Study of Uttarakhand State. Int.J.Curr.Microbiol.App.Sci. 10(01): 2731-2747. doi: https://doi.org/10.20546/ijcmas.2021.1001.318 